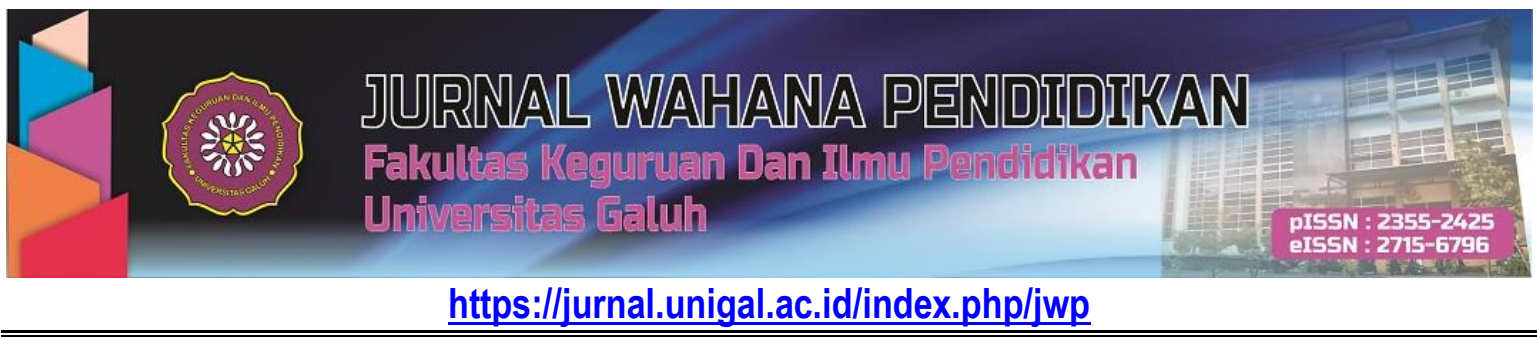

\title{
EFEKTIFITAS HASIL BELAJAR SISWA PADA MATA PELAJARAN BAHASA INDONESIA DENGAN PEMANFAATAN METODE PEMBELAJARAN DRILL (LATIHAN)
}

\author{
Tridays Repelita \\ Universitas Buana Perjuangan Karawang, JI. HS. Ronggo Waluyo, Puseur Jaya, Teluk Jambe Timur, \\ Kabupaten Karawang, Indonesia \\ Email: tridaysrepelita@yahoo.com
}

\begin{abstract}
The role of educators is called vital because the character and selection of teaching-learning methods in the classroom will be able to create a fun and effective teaching-learning process. So, it can stimulate students to be pro-active in the learning process. The method used in this study was an experimental research method. The sampling technique used the cluster random sampling technique. Learning outcomes of the students who were taught without using the Drill Method (Exercise) in Indonesian subjects in class IV SD Negeri 5 Cibadak, Banjarsari, obtained the pre-test scores with an average value $=58.7$ with standard deviation $=15,734$ and variance $=247.56$. The post-test scores obtained with an average value $=62.286$ with a standard deviation $=19.072$ and variance $=363.74$. Learning outcomes of students who were taught by using the Drill Method (Exercise) obtained the pre-test scores with an average value $=59$ with standards deviation $=16,170$ and variance $=261,471$. The post-test scores obtained with an average value $=66.285$ with a standard deviation $=20.195$ and a variance $=407.86$.
\end{abstract}

Keywords: Learning Outcomes, Drill Learning Methods, Indonesian

\begin{abstract}
ABSTRAK
Peran pendidik disebut vital karena, dengan karakter dan pemilihan model dan metode pembelajaran di ruang kelas akan mampu menciptakan sebuah proses pembelajaran yang menyenangkan dan efektif, sehingga mampu merangsang peserta didik untuk pro aktif dalam proses pembelajaran. Metode yang digunakan dalam penelitian ini adalah metode penelitian eksperimen. Teknik sampling dengan menggunakan tehnik clauster random sampling. Hasil belajar peserta didik yang diajarkan tanpa menggunakan Metode Drill(Latihan) pada mata pelajaran Bahasa Indonesia di kelas IV SD Negeri 5 Cibadak, Kecamatan Banjarsari, yaitu dengan nilai tes awal diperoleh dari nilai pre test yaitu dengan nilai rata-rata $=58,7$ dengan standar deviasi $=15,734$ dan varians $=247,56$. Sedangkan untuk nilai post tes diperoleh dengan nilai rata-rata $=62,286$ dengan standar deviasi $=19,072$ dan varians $=363,74$. Hasil belajar peserta didik yang melaksanakan pembelajaran dengan menggunakan Metode Drill (Latihan) pada mata pelajaran Bahasa Indonesia di kelas IV SD Negeri 5 Cibadak, Kecamatan Banjarsari, yaitu dengan nilai tes awal diperoleh dari nilai pre test yaitu dengan nilai rata-rata $=59$ dengan standar deviasi $=16,170$ dan varians $=261,471$. Sedangkan untuk nilai post tes diperoleh dengan nilai rata-rata $=66,285$ dengan standar deviasi $=20,195$ dan varians $=407,86$.
\end{abstract}

Kata Kunci: Hasil Belajar, Metode Pembelajaran Drill, Bahasa Indonesia

Cara sitasi:

Repelita, Tridays. (2020). Efektifitas Hasil Belajar Siswa pada Mata Pelajaran Bahasa Indonesia dengan Pemanfaatan Metode Pembelajaran Drill (Latihan). Jurnal Wahana Pendidikan, 7 (1), 71-76. 


\section{PENDAHULUAN}

Aspek paling utama dalam upaya pengembangan suatu bangsa yaitu aspek pendidikan. Pendidikan berperan penting dalam upaya mencerdaskan kehidupan bangsa. Setiap orang yang berkaitan dengan bidang pendidikan diharuskan untuk berperan secara maksimal dan penuh tanggung jawab agar kualitas pendidikan bisa berkembang lebih baik. Pendidikan itu sendiri merupakan sebuah aspek yang utama dalam rangka untuk menghasilkan generasi-generasi yang cerdas dan terampil dan berkarakter sebagai salah satu syarat menuju sebuah bangsa yang berkualitas, terutama dalam menjawab kesiapan Bangsa Indonesia untuk menyongsong persaingan global yang semakin ketat. Problematika sektor pendidikan yang paling berpengaruh terhadap output lulusan saat ini yaitu mengenai mutu atau kualitas pendidikan itu sendiri. Upaya-upaya revitalisasi sektor pendidikan terus digaungkan oleh pemerintah demi terciptanya mutu pendidikan yang berkualitas dan berkarakter.

Pendidikan merupakan sebuah proses yang tersusun dengan sistematik untuk mewariskan atau mentransmisikan budaya dari para pendidik kepada generasi penerus bangsa. Proses tersebut mengandung sebuah makna terhadap sebuah tindakan asasi yaitu pemilihan atau seleksi keterampilan, fakta, nilai, sikap yang paling berharga dan penting untuk diwariskan kepada generasi penerus Bangsa.

Tujuan dari pendidikan yaitu sebagai jembatan, membuka jalan atau mentransformasikan terjadinya perubahan-perubahan dalam tingkah laku peserta didik menjadi seorang individu yang sesuai dengan apa yang diharapkan. Pendidikan membantu anak dalam pembentukan dirinya sebagai mahluk individu dan mahluk sosial. Pendidikan sebagai hasil meliputi perubahan yang telah terjadi pada diri individu selama partisipasinya dalam proses pendidikan yang dialaminya (Rosdiana, 2009: 23-24).

Peran pendidik dalam proses pembelajaran sangatlah vital, hal tersebut juga menjadi sebuah semangat yang dibawa oleh seorang pendidik, khususnya pendidik dalam mata Bahasa Indonesia. Peran pendidik disebut vital karena, dengan karakter dan pemilihan model dan metode pembelajaran di ruang kelas akan mampu menciptakan sebuah proses pembelajaran yang menyenangkan dan efektif, sehingga mampu merangsang peserta didik untuk pro aktif dalam proses pembelajaran. Menurut prespektif beberapa peserta didik, mata pelajaran Bahasa merupakan sebuah mata pelajaran yang dianggap tidak terlalu sukar dan menyenangkan. Akan tetapi, tidak seluruhnya peserta didik memiliki pandangan serupa ada kalanya sebagian peserta didik menganggap mata pelajaran bahasa indonesia adalah mata pelajaran yang tidak mereka minati. Kurang minatnya peserta didik terhadap mata pelajaran Bahasa Indonesia ini dipengaruhi oleh beberapa faktor yaitu:

1. Pada saat kegiatan proses pembelajaran pendidik yang mengampu mata pelajaran Bahasa Indonesia tidak menggunakan model dan metode pembelajaran yang efektif dan inovatif, sehingga peserta didik merasa bosan dan kurang tertarik terhadap mata pelajaran Bahasa Indonesia. 
2. Dari faktor pendidik yang mengampu mata pelajaran Bahasa Indonesia secara gestur dan penampilan dianggap oleh siswa kurang menarik sehingga semangat belajar peserta didik kurang maksimal.

3. Dari faktor internal peserta didik sendiri yang memiliki kekurangn minat untuk mata pelajaran Bahasa Indonesia.

Menurut beberapa riset yang telah dilaksanakan, diantaranya Nuryati, N. (2019) dan Parida, I. (2019) dapat disimpulkan yaitu faktor penyebab kompetensi Bahasa rendah diakibatkan peserta didik yang tidak mampu memahami urgensi mata pelajaran Bahasa yang diajarkan oleh pendidik dan kondisi proses pembelajaran pada mata pelajaran tersebut yang cenderung monoton, sehingga mengakibatkan peserta didik merasakan kebosanan dalam proses pembelajaran di ruang kelas. Apabila dalam proses pembelajaran pada mata pelajaran Bahasa Indonesia tidak menggunakan model dan metode yang berfariasi akan menimbulkan efek yang negatif yaitu tidak munculnya stimulus bagi peserta didik dalam kegiatan pembelajaran sehingga akan membentuk ketidak pedulian peserta didik terhadap mata pelajaran tersebut.

Selain problematika di atas, faktor penyebab lain kompetensi peserta didik pada mata pelajaran Bahasa Indonesia dapat dikategorikan rendah yaitu sikap dari peserta didik itu sendiri yang cenderung menganggap mudah dalam mempelajari mata pelajaran Bahasa Indonesia. peserta didik beranggapan bahwa Bahasa Indonesia merupakan bahasa keseharian sehingga peserta didik kurang serius dalam proses pembelajaran. Hal tersebut sangat berdampak bagi kualitas peserta didik, khususnya dalam pemahaman mata pelajaran Bahasa Indonesia yang baik dan benar.

Dari pemaparan berbagai problematika yang terjadi dalam proses kegiatan pembelajaran pada mata pelajaran Bahasa Indonesia di atas, peneliti mempunyai sebuah inisiatif untuk menganalisis perbedaan hasil belajar peserta didik dengan menggunakan metode Drill (Latihan). Metode merupakan cara yang harus ditempuh dalam proses pembelajaran. Metode Drill (Latihan) yaitu cara dalam proses pembelajaran yang dilakukan oleh pendidik dengan strategi melatih ketangkasan atau keterampilan peserta didik mengenai materi pembelajaran yang telah direncanakan dan disampaikan. Biasanya metode Drill (Latihan) ini digunakan dalam materi pembelajaran yang bersifat motorik seperti pelajaran baca tulis dan keterampilan, serta materi pembelajaran yang berkaitan dengan kecakapan mental peserta didik dalam artian untuk melatih kecepatan berfikir peserta didik. Dengan waktu yang relatif singkat, berfikir peserta didik akan mampu untuk memahami dan menguasai keterampilan tertentu, bersikap disiplin dan memiliki pengetahuan yang komprehensif, khususnya dalam mata pelajaran Bahasa Indonesia. 


\section{METODE PENELITIAN}

Metode yang digunakan dalam penelitian ini adalah metode penelitian eksperimen, dalam rangka pengumpulan data, sampel terdiri dari dua kelas yaitu kelas eksperimen dan kelas kontrol. Setiap desain eksperimen harus memiliki tiga komponen: kelompok perlakuan, kelompok kontrol, dan penugasan secara acak untuk kelompok perlakuan kontrol (Syaukani, 2015: 22).

Teknik sampling dengan menggunakan tehnik clauster random sampling digunakan bilamana populasi tidak terdiri dari individu-individu, melainkan terdiri dari kelompok-kelompok individu atau clauster dengan catatan anggota berasal dari kelompok-kelompok yang mempunya karakteristik yang sama (homogen). Sampel yang diteliti ada dua kelas yaitu kelas IV (A) yang menjadi kelas eksperimen dan diberikan tindakan Metode Drill (Latihan) dan IV (B) yang menjadi kelas kontrol (pembanding) yang dalam proses pembelajarannya menggunakan model pembelajaran konvensional.

\section{HASIL DAN PEMBAHASAN}

Penelitian ini bertujuan untuk mengetahui pengaruh penggunaan Drill (Latihan) terhadap hasil belajar peserta didik pada mata pelajaran Bahasa Indonesia di kelas IV pada materi mengenai pantun SD Negeri 5 Cibadak, Kecamatan Banjarsari.

Penelitian ini dilakukan di SD Negeri 5 Cibadak, Kecamatan Banjarsari yang melibatkan dua kelas yaitu yaitu kelas eksperimen dan kelas kontrol. Pada kelas eksperimen diberikan perlakuan dengan menggunakan Metode Drill (Latihan) sedangkan pada kelas kontrol diberi perlakuan dengan menggunakan Metode Konvensional. Setelah diberikan perlakuan yang berbeda pada kelas eksperimen dan kelas kontrol, kedua kelas tersebut diberikan pre-test untuk mengetahui kompetensi awal peserta didik. Adapun nilai rata-rata untuk kelas eksperimen adalah 59 dan untuk kelas kontrol adalah 58,7. Berdasarkan varians yang homogen.

Setelah diketahui kompetensi awal pada kedua kelas, selanjutnya peserta didik mengimplementasikan pembelajaran dengan metode yang berbeda pada materi pantun. Peserta didik pada kelas eksperimen melaksanakan pembelajaran dengan Metode Drill (Latihan) dan Peserta didik pada kelas kontrol melaksanakan pembelajaran dengan Metode Konvensional. Setelah diberi perlakuan yang berbeda pada kelas eksperimen dan kelas kontrol, pada akhir pertemuan setelah materi selesai disampaikan, peserta didik diberikan post-test untuk mengetahui hasil belajar dari peserta didik. mengenai nilai rata-rata post-test pada kelas eksperimen adalah 66,285 sedangkan pada kelas kontrol adalah 62,286. Dari pengujian yang dilakukan melalui post-test yang diberikan, diperoleh bahwa kedua kelas memiliki varians yang homogen.

Berdasarkan rata-rata nilai post-test kedua kelas, terlihat bahwa rata-rata nilai post-test kelas eksperimen lebih tinggi dibandingkan dengan rata-rata nilai post test kelas kontrol dengan menggunakan 
uji t. Diperoleh bahwa Ho ditolak Pada taraf signifikansi $\alpha=0,05$ dan $d k=n 1+n 2-2=35+35-2=68$. Maka harga $t_{(0,05: 68)}=1,668$. Dengan demikian nilai thitung dengan $t_{\text {tabel }}$ diperoleh $t_{\text {hitung }}>t_{\text {tabel }} y a i t u 3,572>1,668$. Hal ini berarti $\mathrm{Ho}$ ditolak dan $\mathrm{Ha}$ diterima yang berarti bahwa terdapat pengaruh penggunaan Metode Drill (Latihan) dalam meningkatkan hasil belajar peserta didik pada mata pelajaran Bahasa Indonesia dikelas IV pada materi mengenai pantun SD Negeri 5 Cibadak, Kecamatan Banjarsari.

Hal tersebut koheren dengan Metode pembelajaran yang digunakan oleh peneliti yaitu dengan menggunakan Drill (Latihan). Menurut Roestiyah NK dalam Suprihatiningsih (2016: 37-38), Metode Drill (Latihan) adalah tehnik cara mengajar, dimana peserta didik melaksanakan latihan-latihan agar memiliki ketangkasan atau keterampilan yang lebih tinggi dari apa yang telah dipelajari. Latihan yang praktis, mudah dilakukan serta teratur untuk melakukan pembinaan peserta didik dalam peningkatan keterampilan.

Berdasarkan hasil observasi yang telah dilaksanakan pada peserta didik kelas IV di SD Negeri 5 Cibadak, Kecamatan Banjarsari, ketika diberi pembelajaran terhadap kelas eksperimen dengan menggunakan Metode Drill (Latihan) materi pantun diperoleh hasil yang baik, hal ini dibuktikan oleh peserta didik yang antusias dalam mengikuti proses pembelajaran. Dapat dianalisisdari sikap peserta didik yang saling menghargai khususnya kepada guru dan umumnya kepada sesama teman, proses pembelajaran yang aktif dan efektif, bertanggung jawab dalam menyelesaikan project-project yang diberikan oleh pendidik, bekerja sama dengan baik dalam kelompok, dan peningkatan mental peserta didik dalam menyampaikan hasil jawabannya kepada guru dan rekan-rekannya di kelas. Untuk itu, proses pembelajaran yang dilakukan dengan Metode Drill (Latihan) sangat sesuai dengan tujuan pembelajaran yang ingin dicapai.

\section{KESIMPULAN}

Berdasarkan pemaparan di atas, maka dapat disimpulkan bahwa hasil belajar peserta didik yang diajarkan tanpa menggunakan Metode Drill (Latihan) pada mata pelajaran Bahasa Indonesia di kelas IV SD Negeri 5 Cibadak, Kecamatan Banjarsari, yaitu dengan nilai tes awal diperoleh dari nilai pre-test yaitu dengan nilai rata-rata $=58,7$ dengan standar deviasi $=15,734$ dan varians $=247,56$. Sedangkan untuk nilai post-test diperoleh dengan nilai rata-rata $=62,286$ dengan standar deviasi $=19,072$ dan varians $=363,74$. Hasil belajar peserta didik yang melaksanakan pembelajaran dengan menggunakan Metode Drill (Latihan) pada mata pelajaran Bahasa Indonesia di kelas IV SD Negeri 5 Cibadak, Kecamatan Banjarsari, yaitu dengan nilai tes awal diperoleh dari nilai pre test yaitu dengan nilai rata-rata $=59$ dengan standar deviasi $=16,170$ dan varians $=261,471$. Sedangkan untuk nilai post tes diperoleh dengan nilai rata-rata $=66,285$ dengan standar deviasi $=20,195$ dan varians $=407,86$. Terdapat sebuah perkembangan yang signifikan antara penggunaan Metode Drill(Latihan) terhadap hasil belajar peserta didikpada mata pelajaran Bahasa 
Indonesia di kelas IV SD Negeri 5 Cibadak, Kecamatan Banjarsari. Hal ini dibuktikan dengan uji "t" pada dua kelas di mana thitung $>t_{\text {tabel }}$ yaitu 3,572>1,668 dengan taraf signifikansi 0,05.

\section{REKOMENDASI}

Bagi pendidik yang mengampu mata pelajaran Bahasa Indonesia supaya selektif dalam penggunaan metode pembelajaran agar tercipta kondisi pembelajaran yang efektif dan inovatif serta sesuai dengan materi pembelajaran yang disampaikan sehingga Peserta didik akan lebih tertarik dan termotivasi untuk mempelajari mata pelajaran Bahasa Indonesia serta dapat meningkatkan hasil belajarnya. Salah satunya adalah dengan menggunakan Metode Drill (Latihan). Bagi Peserta didik, supaya dapat meningkatkan spirit, keaktifan dan keberanian dalam pembelajaran pada mata pelajaran Bahasa Indonesia. Peserta didik juga dapat saling memotifasi dan membantu untuk menyelesaikan tugastugas, saling bertukar informasi dan ilmu yang diperoleh.

\section{DAFTAR PUSTAKA}

Nuryati, N. (2019). upaya Meningkatkan Kemampuan Siswa Membaca Artikel Dengan Membaca Cerpen Melalui Penggunaan Teknik Kecepatan Efektif Membaca (KEM) (PTK Di Kelas IX-A SMP Negeri 14 Tasikmalaya). Jurnal Wahana Pendidikan 4 (2), 12-22.

Parida, I. (2019). Penerapan Strategi Scaffolding Dapat Meningkatkan Kemampuan Menulis Kalimat Simple Present Tense Sederhana. Jurnal Wahana Pendidikan 5 (3), 64-71.

Rosdiana A. Bakar. (2009). Pendidikan Suatu Pengntar. Bandung: Cita Pustaka Media Perintis.

Suprihatiningsih. (2016). Perspektif Manajemen Pembelajaran Program Keterampilan. Yogyakarta: Deepublish.

Syaukani. (2015). Metode Penelitian. Medan: Perdana Publishing. 